\title{
FLUVIRUCINS $A_{1}, A_{2}, B_{1}, B_{2}, B_{3}, B_{4}$ AND $B_{5}$, NEW ANTIBIOTICS ACTIVE AGAINST INFLUENZA A VIRUS \\ III. THE STEREOCHEMISTRY AND ABSOLUTE CONFIGURATION OF FLUVIRUCIN $\mathrm{A}_{1}$
}

\author{
Nobuaki Naruse, Masataka Konishi and Toshikazu OKI \\ Bristol-Myers Squibb Research Institute, \\ 2-9-3 Shimo-meguro, Meguro-ku, Tokyo 153, Japan \\ Yoshinobu INOUYe and Hiroshi KaKisawa* \\ Department of Chemistry, University of Tsukuba, \\ Tennodai, Tsukuba, Tbaraki 305, Japan \\ (Received for publication January 14, 1991)
}

\begin{abstract}
Fluvirucin $\mathrm{A}_{1}$ was established as $(2 R, 3 S, 6 R, 10 S)$-3-[(3-amino-3,6-dideoxy- $\alpha$-L-talopyranosyl)oxy]-2,6-dimethyl-10-ethyl-13-tridecanelactam by chemical, spectroscopic, and X-ray crystallographic analyses.
\end{abstract}

Fluvirucins are new antibiotics isolated from the fermentation broth of unidentified actinomycete species and show potent inhibitory activity against influenza $A$ virus. ${ }^{1,2)}$ The structure 1 was proposed for the major component, fluvirucin $A_{1}$, based on various spectroscopic and chemical properties. The 14-membered macrocyclic lactam was the first such aglycone from a natural source but there remained a question that no direct connectivity between C-11 and C-12 was observed in the 2D-incredible natural abundance double quantum transfer experiment (INADEQUATE) spectrum. The stereochemistry of the sugar part was established as 3-amino-3,6-dideoxy-L-talose but that of the aglycone remained uncertain. We report here several spectroscopic and chemical properties of $\mathbf{1}$ and a single crystal X-ray analysis of triacetyl derivative 2 of 1 to confirm the structure and the absolute configuration of the 14-membered macrocycle. Hydrolysis of fluvirucin $A_{1}(1)$ with methanolic hydrogen chloride afforded an aglycone, named fluvirucinine $\mathrm{A}_{1}$ (3) together with two anomeric sugars. ${ }^{2)}$ When a mesylate 4 derived from 3 was treated with 1,8-diazabicyclo[5.4.0] undec-7-ene (DBU) in $N, N$-dimethylformamide at $100^{\circ} \mathrm{C}$ for 4 hours, three dehydration-products 5,6 , and 7 were isolated in 36,13 , and $22 \%$, respectively (Scheme 1). Both $\mathbf{5}$ and 6 have an olefinic double bond and the structures were easily elucidated by ${ }^{1} \mathrm{H}$ NMR spectroscopy. The remaining 7 contained a $\beta$-lactam skeleton (IR $\left.1740 \mathrm{~cm}^{-1}\right)$ and the small coupling constant $(J=2.2 \mathrm{~Hz})$ between the adjacent protons on the 4-membered ring requires these two hydrogens to be trans. As the $\beta$-lactam ring can be considered to derive through an $\mathrm{SN}_{2}$-displacement mechanism, the stereochemistry of the original $\mathrm{C}-2$ and $\mathrm{C}-3$ substituents is estimated as trans. The large coupling constant between $\mathrm{C} 2-\mathrm{H}$ and $\mathrm{C} 3-\mathrm{H}$ in $\mathbf{4}(J=10.3 \mathrm{~Hz})$ or an acetate of $\mathbf{3}(J=9.4 \mathrm{~Hz})^{2)}$ supports this assignment.

As the $\mathrm{C} 3-\mathrm{OH}$ may be equatorially oriented, application of the MosHeR ${ }^{3)}$ or TrosT method ${ }^{4)}$ to determine the absolute stereochemistry was investigated. The results, shown in Fig. 2, are in accord with the prediction that the absolute stereochemistry of C-3 is $S$, though most of the protons on the 14-membered ring could not be assigned due to the overlap of the signals. The configuration of remaining C- 6 and C-10 
Fig. 1. Absolute structures of fluvirucin $A_{1}$ (1) and fluvirucinine $A_{1}$ (3), and their derivatives.<smiles>[R6][C@H]1[C@H](N)[C@@H](O)[C@H](O[C@H]2CC[C@H](C)CC[C@H](CC)CCCCNC(=O)[C@@H]2C)O[C@@H]1C</smiles><smiles>[R9][C@@H](CC[C@@H](C)CCCCC(CC)CC)[C@@H](C)C(=O)NCCCC(C)C</smiles>

$$
\begin{array}{ll}
1 & R=H \\
2 & R=A c
\end{array}
$$

$$
\begin{array}{rl}
\mathbf{3} & \mathrm{R}=\mathrm{H} \\
\mathbf{4} & \mathrm{R}=\mathrm{Ms} \\
\mathbf{8} & \mathrm{R}=(+)-\mathrm{MTPA} \\
\mathbf{9} & \mathrm{R}=(-)-\mathrm{MTPA} \\
\mathbf{1 0} & \mathrm{R}=(-) \text {-MPA } \\
\mathbf{1 1} & \mathrm{R}=(+)-\mathrm{MPA}
\end{array}
$$

Scheme 1.

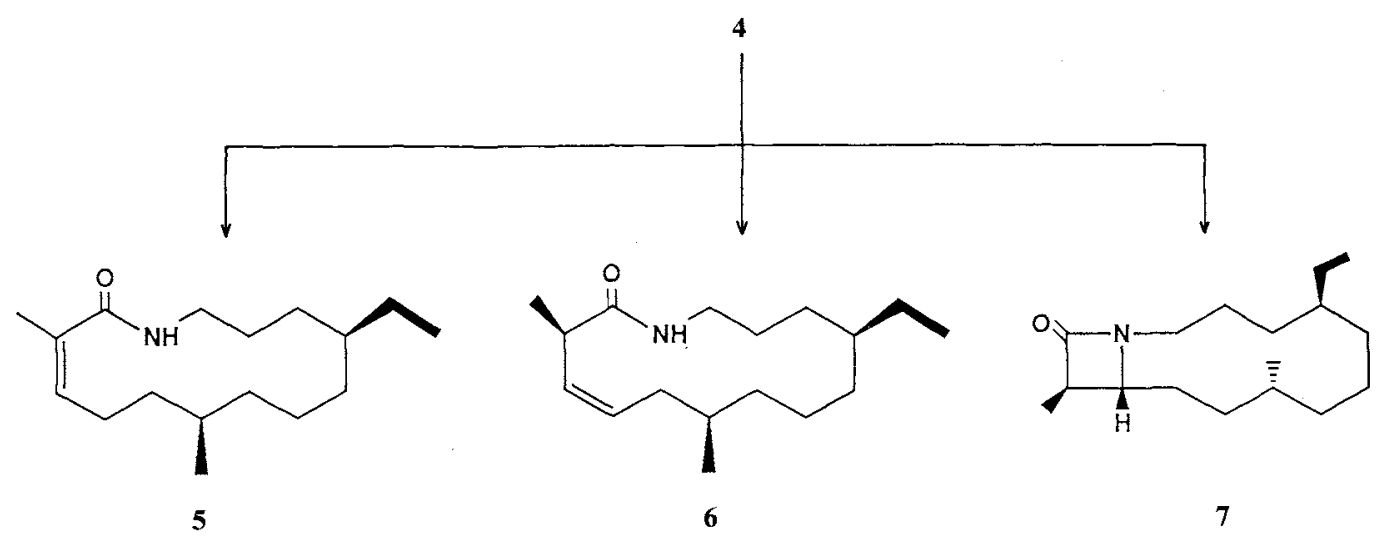

Fig. 2. Chemical shifts differences.

$R-(+)-$ and $S-(-)$-MTPA esters: $\Delta \delta$ in $\mathrm{Hz}(400 \mathrm{MHz})=\delta(S)-\delta(R)(\mathrm{A}), R-(-)-$ and $S-(+)-\mathrm{MPA}$ esters: $\Delta \delta$ in $\mathrm{Hz}(400 \mathrm{MHz})=\delta(R)-\delta(S)(\mathrm{B})$.

(A)

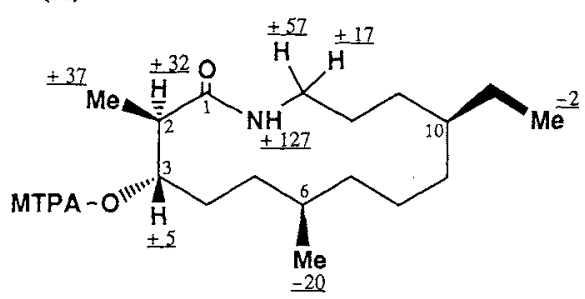

(B)

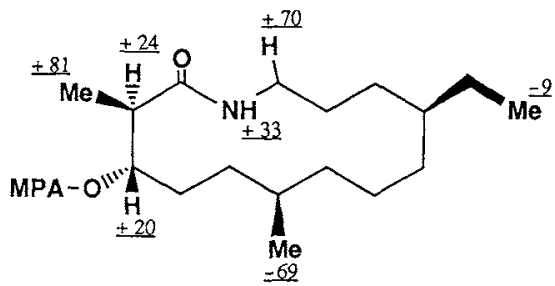

could not yet be clarified by a chemical or spectroscopic method.

We finally tried a single crystal X-ray analysis of 2 to confirm unambiguously the structure and the absolute configuration of the 14-membered macrolactam. 2 was recrystallized from acetone to give colorless rods with one equivalent of acetone as solvent of crystallization. The crystallographic data are summarized as follows: monoclinic, $P 2_{1} ; a=8.317(1), b=28.472(3), c=8.132(1) \AA, \beta=110.43(1)^{\circ}, V=1805(5) \AA^{3}, Z=2$; $\mathrm{D}_{\mathrm{m}}=1.14(1), \mathrm{D}_{\text {calc }}=1.13 \mathrm{~g} / \mathrm{cm}^{3}$.

Several direct attempts with various starting phase-sets estimated from a convergence map failed to 
Fig. 3. ORTEP drawing ${ }^{10}$ of the major conformer of 2 with thermal ellipsoids scaled at the $50 \%$ probability level and numbering scheme.

H-Atoms are calculated and are represented by circles of radius $0.1 \AA$.
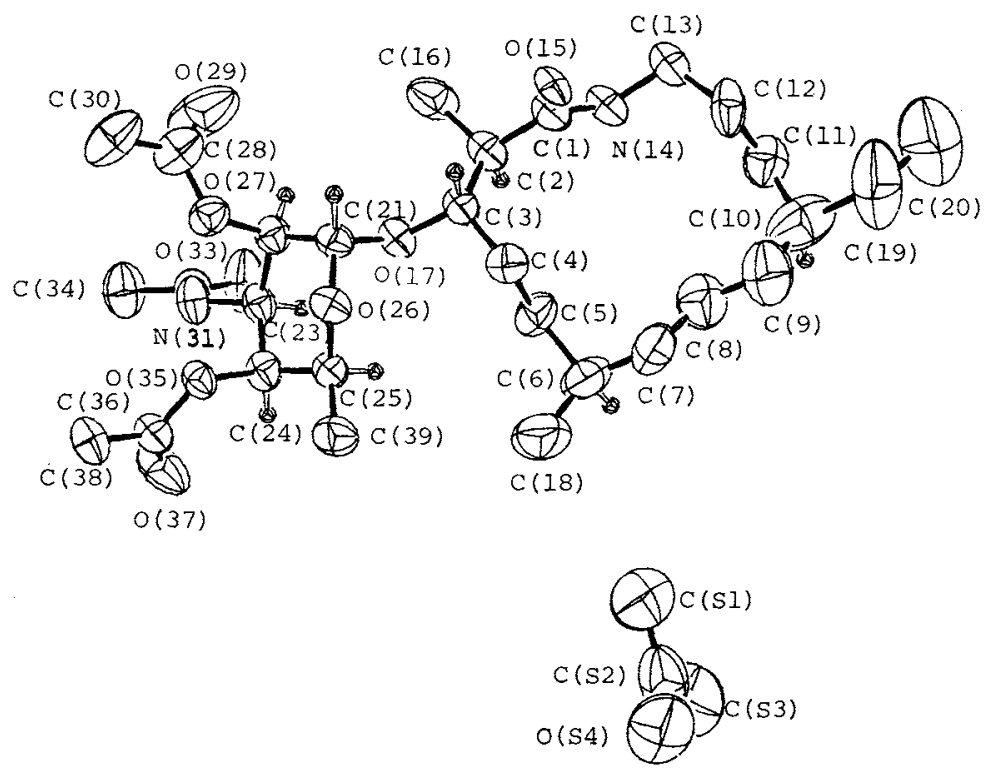

solve the structure. The RANTAN approach in MULTAN11/82 $2^{5)}$ finally succeeded in location of 20 atoms (the sugar part) on the $E$-map. Successive weighted Fourier syntheses revealed the position of the remained non-hydrogen atoms except an ethyl group. The structure was refined by the full-matrix least-squares method (SHELX76). ${ }^{6}$ The atomic scattering factors were taken from International Tables for X-Ray Crystallography. ${ }^{7)}$ All numerical calculations were carried out on a Facom M780/20 computer at the Science Information Processing Center, University of Tsukuba.

After isotropic refinement on 37 atoms, weighted D-Fourier syntheses found the ethyl group and solvent (acetone). Isotropic refinement on all non-hydrogen atoms converged the $R$ factor to 0.154 ; at this stage a disorder was found around the 14-membered ring. Two conformations were estimated with an occupancy of 0.7 and 0.3 . Since several bond-lengths in the disordered part, however, had not been converged to the normal values, the bond lengths in the minor part were fixed to $1.540 \AA$ with e.s.d. $=0.001$ in the final stage. One reflection (020) considered to suffer to a secondary extinction was omitted. Final blocked full-matrix least squares with anisotropic for non-hydrogen atoms and isotropic for those in the minor disordered part converged the $R$ factor to $0.098\left({ }_{w} R=0.100, \mathrm{~S}=3.72\right)$. Final weighting scheme was $\omega=2.9 /\left[\sigma^{2}(\mathrm{Fo})+0.0012 \mathrm{~F}^{2}\right]$. The ratio of maximum least-squares shift to error was less than 0.1 .

Molecular structure of the major conformer with atomic numbering scheme is shown in Fig. $3 .^{\dagger}$

The 14-membered lactam skeleton 1 was unequivocally confirmed including the substituents correctly positioned. Since the absolute configuration of the sugar had been elucidated as 3-amino-3,6-dideoxy-Ltalose, ${ }^{2}$ those on the aglycone were established as $2 R, 3 S, 6 R, 10 S$. The definition of $2 R, 3 S$ is accord with the result obtained by chemical and spectroscopic methods as mentioned above.

\footnotetext{
$\dagger$ Atomic parameters, selected bond lengths, and tortion angles of the 14-membered lactam and the sugar are deposited in Cambridge Crystalographic Data Centre.
} 
Fig. 4. Diamond-lattice representations.

Major (A) and minor (B) conformations.

(A)

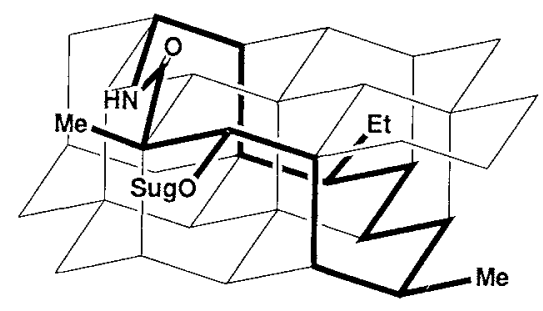

(B)

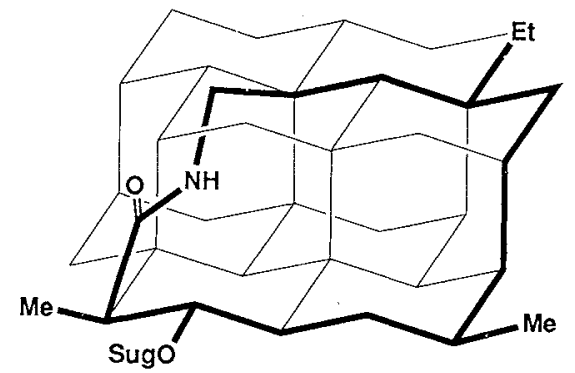

The characteristic feature of the crystal structure is that the 14-membered lactam ring is not in a single conformation. The large thermal parameters and abnormal bond lengths of several atoms ${ }^{\dagger}$ show that other conformational isomers are still possible together with disorder of the ethyl group. Two conformations obtained are shown schematically on the diamond lattice in Fig. 4. The C13-N14-C1-C2-C3 regions of both conformers are essentially same with $\mathrm{C} 3-\mathrm{O}$-sugar in an equatorial position. The difference is detected in three $-\mathrm{CH}_{2}-\mathrm{CH}_{2}$ - units (-C4-C5-, -C7-C8-, and -C11-C12-). The conformations are not in accord with those of the 14-membered lactone antibiotics, erythromycin $\mathrm{A}^{8)}$ or oleandomycin derivatives. ${ }^{97}$ The difference may arise by the presence of many substituents in the latter cases, in which the conformation should be fixed by the steric environment of the substituents.

\section{Experimental}

The mp's are uncorrected. IR spectra were determined on a Jasco IR-810 spectrometer. ${ }^{1} \mathrm{H}$ NMR spectra were recorded on a Jeol JNM-GX $400(400 \mathrm{MHz})$ and chemical shifts were obtained relative to $\mathrm{CDCl}_{3}$ as an internal standard.

Mesylate (4)

A mixture of $200 \mathrm{mg}$ of 3 and $1 \mathrm{ml}$ of methanesulfonyl chloride in $10 \mathrm{ml}$ of dry pyridine was stirred at room temperature for 16 hours. After the whole had been poured onto ice-water, products were extracted with EtOAc $(70 \mathrm{ml} \times 2)$. The organic layer was washed with $1 \mathrm{M} \mathrm{HCl}$, a satd $\mathrm{NaHCO}_{3}$ soln, and water (each $50 \mathrm{ml} \times 2$ ) and was dried over anhydrous $\mathrm{Na}_{2} \mathrm{SO}_{4}$. Evaporating the solvent gave $220 \mathrm{mg}$ of 4 as solids. Crystallization from $\mathrm{CHCl}_{3}-\mathrm{MeOH}$ afforded a pure 4. $\mathrm{MP} 216 \sim 217^{\circ} \mathrm{C}$; $\mathrm{IR} v_{\max }(\mathrm{KBr}) \mathrm{cm}^{-1} 1320$, $1160 ;{ }^{1} \mathrm{H}$ NMR $\left(\mathrm{CDCl}_{3}-\mathrm{CD}_{3} \mathrm{OD}\right) \delta 4.91(1 \mathrm{H}, \mathrm{dt}, J=10.3$ and $4.3 \mathrm{~Hz}, 3-\mathrm{H}), 3.71(1 \mathrm{H}, \mathrm{m}, 13-\mathrm{H}), 3.08(3 \mathrm{H}$, s, 3-OMs), $2.69(1 \mathrm{H}, \mathrm{dq}, J=10.3$ and $6.8 \mathrm{~Hz}, 2-\mathrm{H}), 2.64(1 \mathrm{H}, \mathrm{m}, 13-\mathrm{H}), 1.27\left(3 \mathrm{H}, \mathrm{d}, J=6.8 \mathrm{~Hz}, 2-\mathrm{CH}_{3}\right)$, $0.91\left(3 \mathrm{H}, \mathrm{d}, J=6.8 \mathrm{~Hz}, 6-\mathrm{CH}_{3}\right), 0.87\left(3 \mathrm{H}, \mathrm{t}, J=7.3 \mathrm{~Hz}, 10-\mathrm{CH}_{2} \mathrm{CH}_{3}\right)$.

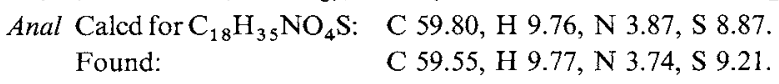

\section{DBU Treatment on 4}

To a suspension of $184 \mathrm{mg}$ of $4 \mathrm{in} 10 \mathrm{ml}$ of DMF, there was added $1.5 \mathrm{ml}$ of DBU and the mixture was heated at $100^{\circ} \mathrm{C}$ for 4 hours. After the whole had been cooled to room temperature, EtOAc was added up to $150 \mathrm{ml}$ and the solution was washed with $1 \mathrm{M} \mathrm{HCl}$, a satd $\mathrm{NaHCO}_{3}$ soln, and water (each $100 \mathrm{ml} \times 2$ ). The organic layer was dried over anhydrous $\mathrm{Na}_{2} \mathrm{SO}_{4}$ and evaporated to dryness to give a pale yellow solids. Chromatography on silica gel (toluene- $\mathrm{MeOH}, 19: 1)$ afforded 5 (48.5 mg), 6 (17.7 mg), and 7 
$(29.5 \mathrm{mg})$ as white solids.

5: MP 163 165 ${ }^{\circ}$; IR $v_{\max }(\mathrm{KBr}) \mathrm{cm}^{-1} 1660 ;{ }^{1} \mathrm{H} \mathrm{NMR}\left(\mathrm{CDCl}_{3}\right) \delta 5.62(1 \mathrm{H}$, br s, NH), $5.40(1 \mathrm{H}$, ddq, $J=9.0,6.4$ and $1.3 \mathrm{~Hz}, 3-\mathrm{H}), 3.44(1 \mathrm{H}, \mathrm{ddt}, J=13.3,2.1$ and $6.8 \mathrm{~Hz}, 13-\mathrm{H}), 3.26(1 \mathrm{H}, \mathrm{m}, 13-\mathrm{H}), 2.20$ $(1 \mathrm{H}, \mathrm{ddt}, J=13.3,4.7$ and $9.0 \mathrm{~Hz}, 4-\mathrm{H}), 1.94(1 \mathrm{H}, \mathrm{m}, 4-\mathrm{H}), 1.89\left(3 \mathrm{H}, \mathrm{s}, 2-\mathrm{CH}_{3}\right), 0.88(3 \mathrm{H}, \mathrm{d}, J=6.8 \mathrm{~Hz}$, $\left.6-\mathrm{CH}_{3}\right), 0.86\left(3 \mathrm{H}, \mathrm{t}, J=7.3 \mathrm{~Hz}, 10-\mathrm{CH}_{2} \mathrm{CH}_{3}\right)$. NOESY spectrum showed a cross peak between $\mathrm{C} 2-\mathrm{CH}_{3}$ and $\mathrm{C} 3-\mathrm{H}$.

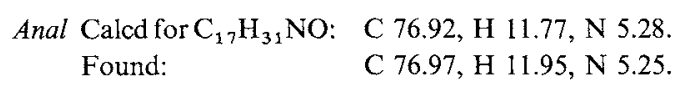

6: MP $172 \sim 174^{\circ} \mathrm{C}$; IR $v_{\max }(\mathrm{KBr}) \mathrm{cm}^{-1} 1660 ;{ }^{1} \mathrm{H}$ NMR $\left(\mathrm{CDCl}_{3}\right) \delta 5.61(1 \mathrm{H}$, br s, NH), $5.53(1 \mathrm{H}$, ddd, $J=11.7,10.3$ and $3.8 \mathrm{~Hz}, 4-\mathrm{H}), 5.42(1 \mathrm{H}$, ddd, $J=11.7,9.0$ and $1.9 \mathrm{~Hz}, 3-\mathrm{H}), 3.53(1 \mathrm{H}, \mathrm{m}, 13-\mathrm{H})$, $2.97(1 \mathrm{H}, \mathrm{m}, 13-\mathrm{H}), 2.91(1 \mathrm{H}, \mathrm{dq}, J=9.0$ and $6.8 \mathrm{~Hz}, 2-\mathrm{H}), 2.16(1 \mathrm{H}$, ddd, $J=13.7,4.4$ and $3.8 \mathrm{~Hz}, 5-\mathrm{H})$, $1.83(1 \mathrm{H}, \mathrm{dt}, J=13.7$ and $10.3 \mathrm{~Hz}, 5-\mathrm{H}), 1.22\left(3 \mathrm{H}, \mathrm{d}, J=6.8 \mathrm{~Hz}, 2-\mathrm{CH}_{3}\right), 0.93\left(3 \mathrm{H}, \mathrm{d}, J=6.8 \mathrm{~Hz}, 6-\mathrm{CH}_{3}\right)$, $0.84\left(3 \mathrm{H}, \mathrm{t}, J=7.3 \mathrm{~Hz}, 10-\mathrm{CH}_{2} \mathrm{CH}_{3}\right)$.

Anal Calcd for $\mathrm{C}_{17} \mathrm{H}_{31} \mathrm{NO}$ : C 76.92, H 11.77, N 5.28.

Found: $\quad$ C $76.82, \mathrm{H} 11.88, \mathrm{~N} 5.17$.

7: MP $77 \sim 78^{\circ} \mathrm{C}$; IR $v_{\max }(\mathrm{KBr}) \mathrm{cm}^{-1} 1740 ;{ }^{1} \mathrm{H} \mathrm{NMR}\left(\mathrm{CDCl}_{3}\right) \delta 3.75(1 \mathrm{H}, \mathrm{dt}, J=14.3$ and $8.2 \mathrm{~Hz}$, $13-\mathrm{H}), 3.10(1 \mathrm{H}, \mathrm{dt}, J=8.8$ and $2.2 \mathrm{~Hz}, 3-\mathrm{H}), 2.70(1 \mathrm{H}, \mathrm{dq}, J=2.2$ and $7.3 \mathrm{~Hz}, 2-\mathrm{H}), 2.66(1 \mathrm{H}, \mathrm{ddd}, J=14.3$, 7.8 and $3.3 \mathrm{~Hz}, 13-\mathrm{H}), 1.24\left(3 \mathrm{H}, \mathrm{d}, J=7.3 \mathrm{~Hz}, 2-\mathrm{CH}_{3}\right), 0.89\left(3 \mathrm{H}, \mathrm{d}, J=6.6 \mathrm{~Hz}, 6-\mathrm{CH}_{3}\right), 0.86(3 \mathrm{H}, \mathrm{t}$, $J=7.3 \mathrm{~Hz}, 10-\mathrm{CH}_{2} \mathrm{CH}_{3}$ ).

Anal Calcd for $\mathrm{C}_{17} \mathrm{H}_{31} \mathrm{NO}: \quad \mathrm{C} 76.92, \mathrm{H} 11.77, \mathrm{~N} 5.28$. Found: $\quad$ C 76.77, H 11.88, N 5.28 .

$R-(+)$ - and $S$-(-)- $\alpha$-Methoxy- $\alpha$-(trifluoromethyl)phenylacetyl Esters 8 and 9

A mixture of $13 \mathrm{mg}$ of $3,150 \mu \mathrm{l}$ of $\alpha$-methoxy- $\alpha$-(trifluoromethyl)phenylacetyl chloride $(R-(+)$ MTPAC1), $1 \mathrm{ml}$ of $\mathrm{Et}_{3} \mathrm{~N}$, and $10 \mathrm{mg}$ of 4-dimethylaminopyridine (DMAP) in $2 \mathrm{ml}$ of dichloromethane was stirred at room temperature for 16 hours. EtOAc and ice-water were added to the solution and the whole was stirred for 1 hour. After had been separated, the organic layer was washed with $1 \mathrm{M} \mathrm{HCl}$, satd $\mathrm{NaHCO}_{3}$ soln, and water. After concentrating under reduced pressure, the crude products were purified by preparative TLC (toluene- $\mathrm{MeOH}(17: 3)$ followed with hexane-acetone, 9:1) and column-chromatography on Sephadex LH-20 (MeOH) to afford $15 \mathrm{mg}$ of 8 as white solids. The $S$-(-)-MTPA ester 9 was prepared as similar procedure.

8: MP $185 \sim 187^{\circ} \mathrm{C} ;{ }^{1} \mathrm{H}$ NMR $\left(\mathrm{CDCl}_{3}\right) \delta 7.57(2 \mathrm{H}, \mathrm{m}), 7.42(3 \mathrm{H}, \mathrm{m}), 5.45(1 \mathrm{H}, \mathrm{dd}, J=8.1$ and $4.3 \mathrm{~Hz}$, $\mathrm{NH}), 5.26(1 \mathrm{H}, \mathrm{dt}, J=3.4$ and $8.1 \mathrm{~Hz}, 3-\mathrm{H}), 3.75(1 \mathrm{H}$, ddt, $J=13.7,1.7$ and $8.1 \mathrm{~Hz}, 13-\mathrm{H}), 3.59(3 \mathrm{H}, \mathrm{s})$, $2.50(1 \mathrm{H}, \mathrm{m}, 13-\mathrm{H}), 2.44(1 \mathrm{H}, \mathrm{dq}, J=8.1$ and $7.3 \mathrm{~Hz}, 2-\mathrm{H}), 1.72(1 \mathrm{H}, \mathrm{tt}, J=13.9$ and $3.4 \mathrm{~Hz}, 4-\mathrm{H}), 1.06$ $\left(3 \mathrm{H}, \mathrm{d}, J=7.3 \mathrm{~Hz}, 2-\mathrm{CH}_{3}\right), 0.85\left(3 \mathrm{H}, \mathrm{t}, J=7.3 \mathrm{~Hz}, 10-\mathrm{CH}_{2} \mathrm{CH}_{3}\right), 0.84\left(3 \mathrm{H}, \mathrm{d}, J=7.3 \mathrm{~Hz}, 6-\mathrm{CH}_{3}\right)$.

9: MP $184 \sim 186^{\circ} \mathrm{C} ;{ }^{1} \mathrm{H}$ NMR $\left(\mathrm{CDCl}_{3}\right) \delta 7.54(2 \mathrm{H}, \mathrm{m}), 7.41(3 \mathrm{H}, \mathrm{m}), 5.76(1 \mathrm{H}, \mathrm{dd}, J=8.1$ and $4.3 \mathrm{~Hz}$, $\mathrm{NH}), 5.27(1 \mathrm{H}, \mathrm{dt}, J=3.4$ and $8.6 \mathrm{~Hz}, 3-\mathrm{H}), 3.79(1 \mathrm{H}, \mathrm{ddt}, J=13.7,1.7$ and $8.1 \mathrm{~Hz}, 13-\mathrm{H}), 3.54(3 \mathrm{H}, \mathrm{s})$, $2.64(1 \mathrm{H}, \mathrm{m}, 13-\mathrm{H}), 2.52(1 \mathrm{H}, \mathrm{dq}, J=8.6$ and $7.3 \mathrm{~Hz}, 2-\mathrm{H}), 1.73(1 \mathrm{H}, \mathrm{tt}, J=13.9$ and $3.4 \mathrm{~Hz}, 4-\mathrm{H}), 1.15$ $\left(3 \mathrm{H}, \mathrm{d}, J=7.3 \mathrm{~Hz}, 2-\mathrm{CH}_{3}\right), 0.84\left(3 \mathrm{H}, \mathrm{t}, J=7.3 \mathrm{~Hz}, 10-\mathrm{CH}_{2} \mathrm{CH}_{3}\right), 0.79\left(3 \mathrm{H}, \mathrm{d}, J=6.8 \mathrm{~Hz}, 6-\mathrm{CH}_{3}\right)$.

$R-(-)$ - and $S-(+)-\alpha-$ Methoxyphenylacetic Acid (MPA) Esters 10 and 11

A mixture of $14 \mathrm{mg}$ of $3,53 \mathrm{mg}$ of $R-(-)$-MPA, $10 \mathrm{mg}$ of DMAP, and 1-ethyl-3-(3diethylaminopropyl)carbodiimide hydrochloride in $5 \mathrm{ml}$ of dichloromethane was stirred at room temperature for 16 hours. After concentrating under reduced pressure, $40 \mathrm{ml}$ of EtOAc was added and the whole was washed with a $5 \%$ citric acid soln, water, a $5 \% \mathrm{NaHCO}_{3}$ soln, and water $($ each $30 \mathrm{ml} \times 2$ ). After evaporating the solvent, the residue was purified by preparative TLC (toluene-MeOH, 17:3) and column-chromatography on Sephadex LH-20 (MeOH) to afford $11.5 \mathrm{mg}$ of 10 as white solids. $S$-(+)-MPA ester 11 was prepared by a similar procedure.

10: MP $220 \sim 221^{\circ} \mathrm{C} ;{ }^{1} \mathrm{H}$ NMR $\left(\mathrm{CDCl}_{3}\right) \delta 7.44(2 \mathrm{H}$, br d, $J=7 \mathrm{~Hz}), 7.35(3 \mathrm{H}, \mathrm{m}), 5.70(1 \mathrm{H}, \mathrm{br} \mathrm{dd}$, $J=7.3$ and $4.7 \mathrm{~Hz}, \mathrm{NH}), 5.05(1 \mathrm{H}, \mathrm{dt}, J=2.7$ and $8.8 \mathrm{~Hz}, 3-\mathrm{H}), 4.77(1 \mathrm{H}, \mathrm{s}), 3.63(1 \mathrm{H}, \mathrm{m}, 13-\mathrm{H}), 3.43(3 \mathrm{H}$, s), $2.83(1 \mathrm{H}$, dddd, $J=13.5,7.3,4.7$ and $2.1 \mathrm{~Hz}, 13-\mathrm{H}), 2.39(1 \mathrm{H}, \mathrm{dq}, J=8.8$ and $6.8 \mathrm{~Hz}, 2-\mathrm{H}), 1.09(3 \mathrm{H}$, d, $\left.J=6.8 \mathrm{~Hz}, 2-\mathrm{CH}_{3}\right), 0.83\left(3 \mathrm{H}, \mathrm{t}, J=7.3 \mathrm{~Hz}, 10-\mathrm{CH}_{2} \mathrm{CH}_{3}\right), 0.62\left(3 \mathrm{H}, \mathrm{d}, J=6.8 \mathrm{~Hz}, 6-\mathrm{CH}_{3}\right)$.

11: MP $250 \sim 252^{\circ} \mathrm{C}$; ${ }^{1} \mathrm{H}$ NMR $\left(\mathrm{CDCl}_{3}\right) \delta 7.45(2 \mathrm{H}$, br d, $J=7 \mathrm{~Hz}), 7.37(3 \mathrm{H}, \mathrm{m}), 5.62(1 \mathrm{H}$, br dd, 
$J=7.3$ and $4.7 \mathrm{~Hz}, \mathrm{NH}), 5.00(1 \mathrm{H}, \mathrm{dt}, J=2.6$ and $6.8 \mathrm{~Hz}, 3-\mathrm{H}), 4.78(1 \mathrm{H}, \mathrm{s}), 3.65(1 \mathrm{H}, \mathrm{ddt}, J=13.3,2.6$ and $7.3 \mathrm{~Hz}, 13-\mathrm{H}), 3.42(3 \mathrm{H}, \mathrm{s}), 2.66(1 \mathrm{H}$, dddd, $J=13.3,8.6,4.7$ and $2.1 \mathrm{~Hz}, 13-\mathrm{H}), 2.33(1 \mathrm{H}$, quint, $J=6.8 \mathrm{~Hz}$, $2-\mathrm{H}), 0.88\left(3 \mathrm{H}, \mathrm{d}, J=6.8 \mathrm{~Hz}, 2-\mathrm{CH}_{3}\right), 0.86\left(3 \mathrm{H}, \mathrm{t}, J=7.3 \mathrm{~Hz}, 10-\mathrm{CH}_{2} \mathrm{CH}_{3}\right), 0.79\left(3 \mathrm{H}, \mathrm{d}, J=7.3 \mathrm{~Hz}, 6-\mathrm{CH}_{3}\right)$.

\section{Crystallographic and Diffraction Data Collection of 2}

The crystals were grown from an acetone solution as colorless rods. MP $246 \sim 247^{\circ} \mathrm{C}$ (changed to opaque above $148^{\circ} \mathrm{C}$ due to the solvent loss).

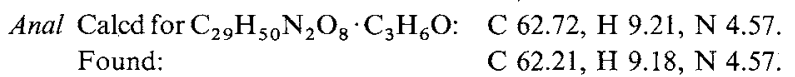

The densities $\left(\mathrm{D}_{\mathrm{m}}\right)$ were measured by flotation in aqueous $\mathrm{KI}$ solution. The unit-cell dimensions were refined by least-squares refinement from 25 reflections with $11^{\circ}<\theta<13^{\circ}$ on an Enraf-Nonius CAD4 automated kappa-axis diffractometer with graphite monochromated $\mathrm{Mo} \mathrm{K} \alpha$ radiation $(50 \mathrm{kV}$ and $26 \mathrm{~mA})$. The diffraction intensities were measured for a single crystal of about $0.4 \times 0.3 \times 0.3 \mathrm{~mm}^{3}$ on the diffractometer up to $2 \theta=60^{\circ} ; 2 \theta-\omega$ scan, the scan rate with $4^{\circ} \mathrm{min}^{-1}$ in $\theta$, the $\omega$ scan width $=0.6+0.35 \tan \theta$. Three standard reflections were measured after every 2 hours. The intensities were corrected for Lorentz, polarization, and decay $(-1.2 \%$ in intensity) but not for absorption. Systematic absence $(\mathrm{k}=2 \mathrm{n})$ indicated unambiguously the space group $P 2_{1}$. Of 5,345 unique reflections, 3,453 of independent structure factors with $|\mathrm{Fo}|>3 \sigma(\mathrm{Fo})$ were used for structure determination.

\section{References}

1) Naruse, N.; O. Tenmyo, K. Kawano, K. Tomita, N. Ohgusa, T. Miyaki, M. Konishi \& T. Oki: Fluvirucins $\mathrm{A}_{1}, \mathrm{~A}_{2}, \mathrm{~B}_{1}, \mathrm{~B}_{2}, \mathrm{~B}_{3}, \mathrm{~B}_{4}$ and $\mathrm{B}_{5}$, new antibiotics active against influenza $\mathrm{A}$ virus. I. Production, isolation, chemical properties and biological activities. J. Antibiotics 44: 733 740, 1991

2) Naruse, N.; T. Tsuno, Y. Sawada, M. Konishi \& T. OkI: Fluvirucins $A_{1}, A_{2}, B_{1}, B_{2}, B_{3}, B_{4}$ and $B_{5}$, new antibiotics active against influenza $A$ virus. II. Structure determination. J. Antibiotics 44: 741 755, 1991

3) OhtANI, I.; T. KUSUMI, M. O. IshitsuKa \& H. KAKISAWA: Absolute configurations of marine diterpenes possessing a xenicane skeleton. An application of an advanced Mosher's method. Tetrahedron Lett. 30: 3147 3150, 1989

4) Trost, B. M.; J. L. Belletire, S. Godleski, P. G. McDougal \& J. M. Balkovec: On the use of the O-methylmandelate ester for establishment of absolute configuration of secondary alcohols. J. Org. Chem. 51:2370 2374, 1986

5) Main, P.; S. J. Fiske, S. E. Hull, L. Lessinger, G. Germain, J. P. Declerce \& M. M. Woolfson: MUltan11/82. A System of Computer Programs for the Automatic Solution of Crystal Structures from X-Ray Diffraction Data. Department of Physics, University of York (England), 1982

6) SHELDRICK, G. M.: SHELX76. Program for Crystal Structure Determination. University of Cambridge (England), 1976

7) Cromer, D. T. \& J. T. Waber: International Tables for X-Ray Crystallography. Vol. 4. p. 99, Kynoch Press, 1974

8) Adachi, T.; S. Morimoto, Y. Watanabe, N. Kamiya \& H. Iwasaki: Crystal and molecular structure of (14R)-14-hydroxy-6-O-methylerythromycin A. J. Antibiotics 42: 1012 1014, 1989

9) Ogura, H.; K. Furuhata, Y. Harada \& Y. IrTaka: Stereochemistry of macrolides. 3. X-ray crystal structure analysis of $11,4^{\prime \prime}$-bis[O-(p-bromobenzoyl) $]$ oleandomycin. J. Am. Chem. Soc. 100: 6733 6737, 1978

10) JoHnSON, C. K.: ORTEPII. Report ORNL-5138. Oak Ridge National Laboratory, U.S.A., 1976 